for many years he delivered lectures for one or other of the Temperance Societies. He was a great admirer of Meissonier's etchings and at one time possessed a fine collection thereof.

\title{
DR. ALFRED OSBORNE
}

DR. ALFRED OSBORNE died at his residence in Alexandria, on November 15, at the age of 68 years. He was the senior ophthalmic practitioner of Egypt, an active member and a previous President of the Archaeological Society, and was as well known to Egyptians as to the British and other European communities of Alexandria.

Dr. Osborne was a descendant of an old Scottish family, and his ancestors settled in Prague, 150 years ago. Thus he performed his military service in the old Austro-Hungarian Army and rèceived an excellent medical and ophthalmological training in the clinics of the late Duke Carl Theodor of Bavaria, the "princely oculist" and father of Her Majesty the Queen of the Belgians.

After a scientific journey in Asia Minor, Dr. Osborne arrived in Alexandria, in 1895, as successor to Dr. Tachau, a famous ophthalmic surgeon, and took charge of the eye section of the European Hospital. Under Osborne's guidance this section developed enormously and eventually contained over 70 beds for inpatients and hundreds of operations were performed every year. The number of out-patients receiving treatment at the clinic was over 4,000 a year. He remained in charge of the eye section for twenty years. On the outbreak of war he returned to Europe and lived in Germany until 1921, when he returned to Alexandria but only to resume private practice.

Osborne was an excellent physician, a skilled surgeon and a fervent member of the Ophthalmological Society of Egypt of which in 1902 he was one of the founders. In 1903, on his advice a donation by Sir Ernest Cassel, of $£ 40,000$, for ophthalmic purposes was utilised in the equipment and maintenance of two travelling clinics for the treatment of eye diseases, the first of their kind in. the country. Now thanks to the enthusiasm of MacCallan, Shahine Pasha and their collaborators there are over fifty clinics, most of them in specially built hospitals, throughout Egypt.

Osborne's great work in fighting the epidemic eye diseases of this country is beyond praise and tens of thousands of sufferers have been cured by his skilful hands. He further found time to write many scientific publications of no inconsiderable value to medicine.

Osborne was a connoiseur of German literature, especially of Goethe, and a great admirer of classic art. He leaves a fine and valuable library and an excellent collection of Graeco-Roman antiquities. His sincere and honest character as well as his happy family life won him the regard and friendship of everybody who knew him and his friends will not forget him.

MAX MeYerhof. 